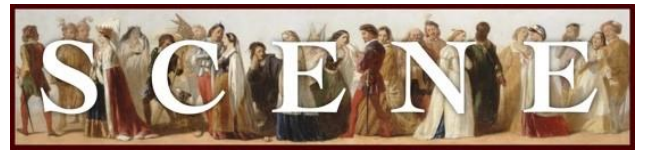

\title{
"Do Statues Dream of Puppet Sheep?"
}

\author{
by Erin Kelly. Written on 2017-08-11. Published in 2017 Issue 2.
}

For the production: The Winter's Tale (2017, Bard on the Beach, Canada). See production details at the end of the review.

BARD ON THE BEACH'S PRODUCTION OF THE WiNTER'S TALE TOOK THE CONCEPT OF A "TALE" very seriously, transforming the play into a story being told by a chorus of masked performers led by Paulina; the group introduced and closed the main action, reminding the audience at the end of why such a magically happy ending might be appropriate for a summer Shakespeare festival by stating "a sad tale's best for winter." The fact that Bard on the Beach's performers were dressed in a stylized version of ancient Greek costume rendered in beautiful jewel tones made the proceedings look like picture-book illustrations. The masks worn by many chorus members and by some actors in minor roles throughout the play recalled classical representations of tragedy and comedy but also drew from cubist experiments for representing the human face. Rather than striving for naturalism, Gibson's production stressed the play's story/dream logic by constantly confronting the audience with visually striking theatrical effects.

It seemed fitting, therefore, that the production staged some of the most unlikely elements of the play using puppets more sculptural than representational. The sheep-shearing festival was made particularly charming by the presence of a few cartoonish sheep that the actors playing shepherds manipulated to walk, cock their heads in puzzlement, and even serve as silent audience members for stage action. The bear that devoured Antigonus was no less terrifying for being so obviously two performers inside of a large construction that evoked the impression of a moving pile of lumber as well as lumbering grizzly. When the stylized creature reared up on its hind legs, its bulk and shadow combined to fill the center of the enormous stage. Yet this production also took time to create lovely small moments of humanity in the play, rendering these them simply and naturalistically. Antigonus became a heroic figure when he stopped running from the bear to distract it from the presence of the infant Perdita it seemed for a moment quite interested in eating. The Shepherd and his Son became more than stereotypical clowns as they began to coo and pull faces to delight and comfort the helpless infant they found. 
The production featured strong performances by Sereana Malani as a very dignified Hermione - she began the play seeming to view her husband (Kevin MacDonald) and his friend Polixenes (Ian Butcher) as overgrown boys. Her response to Leontes's jealousy was an expression of longtested patience, as she understood her husband's immaturity was leading him into not just unfounded jealousy but dangerously impulsive actions that would do as much harm to him and his kingdom as to herself. Andrew Wheeler as Antigonus was as dignified as Hermione, making clear through his body language that he believed an agreement to abandon the infant Perdita on a distant shore was the best of several bad choices, the most dangerous of which would be to leave her with Leontes. Young performers Kaitlin Williams as Perdita and Austin Eckert as Florizel were so innocently affectionate with one another that any threat to their union could not help but seem unfair. And Ben Elliott - a physically agile and fearless comedian who reminds me of a young Jim Carrey - made Autolycus a chaotic but never really dangerous source of fun.

Indeed, Autolycus is a key example of how this production created a strong contrast between Sicilia and Bohemia. In earth-toned clothing made out of loosely woven, roughly constructed, and somewhat ragged fabric, the former courtier turned peddler and thief would be unimaginable among the silvery, cool, smooth world of the opening scenes in Sicilia. That world featured columns, hinting at a classical setting as well as a sense of order and hierarchy. Moving to Bohemia brought the audience to a very different golden plain dominated by a large, abstractly rendered tree whose twisted branches followed a more organic and random, albeit equally lovely, logic. As the final scenes brought characters from Bohemia into Sicilia, the latter kingdom seemed warmer, as though it were blushing with new life, long before the "statue" of Hermione began to move.

In this scene, Paulina seemed very much in control, but no more so than she was during the rest of the production. As well as leading an opening and closing chorus, Paulina here spoke as Time, making explicit her power over how the story was being told and hinting at her potential ability to shape the tale's ending. Lois Anderson brought to this role a stillness and dignity that allowed audiences to attend primarily to her sonorous voice. She seemed particularly powerful in her lack of fear when threatened by the furious Leontes for carrying the infant Perdita to her father. (Note that the performance I saw featured Lois Anderson as Paulina; later in the run, because of scheduling complications, Bard shifted this role to Jennifer Lines who might have put a different spin on the role.)

The overall sense that Paulina was telling, controlling, and perhaps even creating the story of The Winter's Tale made this production seem especially open to the possibility of magic. While the spoken lines remained in which Hermione explains that, with Paulina's help, she had kept 
herself hidden until Perdita returned to Sicilia, several people in the audience I eavesdropped upon while leaving the theater were talking about Hermione coming back from the dead; a student who saw the production on a different date mentioned that she was particularly impressed by how Paulina brought the statue to life. This production infused the play with the power of ancient storytelling to such an extent that any magic or miracle seemed perfectly plausible. In the process, director Paul Dean Gibson reminded Bard audiences of the potential to ancient magic of performance's capacity to awake our wonder.

\section{Production Details}

\section{General}

Title

Year

Theater Company

Theaters

Start Date

End Date

\section{Cast}

King LeONTES

LORD ANTIGONUS

King Polixenes

PRINCE FLORIZEL

QueEn Hermione

PRINCESs PERdita

\section{Creatives}

Puppet Designer
Director
Costume Designer
Set Designer
Lighting Designer
SOUnd Designer
Choreography
ChOREOgRaphy

The Winter's Tale

2017

Bard on the Beach

BMO Mainstage (Canada)

2017-06-22

2017-09-22

\begin{abstract}
KeVIn Macdonald
ANDREW WHEELER

IAN BUTCHER

Austin ECKERT

SEREANA Malani

KaITLIN WILLIAMS
\end{abstract}

HEIDI WILKINSON
DEAN PAUL GIBSON
CARMEN ALATORRE
PAM JOHNSON
GERALD KING
MALCOLM DOW
WENDY GORLING
TRACY POWERS

HEIDI WILKINSON

DEAN PAUL GIBSON

PAM JOHNSON

ERALD KING

WENDY GORLING

TRACY POWERS 